\title{
Screening of entomopathogenic Metarhizium anisopliae isolates and proteomic analysis of secretion synthesized in response to cowpea weevil (Callosobruchus maculatus) exoskeleton ${ }^{\text {ts }}$
}

\author{
André M. Murad ${ }^{\text {a }}$, Raul A. Laumann ${ }^{\text {b }}$, Thaina de A. Lima ${ }^{\text {a }}$, Rubia B.C. Sarmento ${ }^{\text {a }}$, \\ Eliane F. Noronha ${ }^{a}$, Thales L. Rocha ${ }^{b}$, Maria C. Valadares-Inglis ${ }^{b}$, Octávio L. Franco ${ }^{a}, *$ \\ ${ }^{a}$ Centro de Analises Proteômicas e Bioquímicas, Pós-Graduação em Ciências Genômicas e Biotecnologia, UCB, Brasília, DF, Brazil \\ ${ }^{\mathrm{b}}$ Embrapa/Cenargen, Brasilia, DF, Brazil
}

Received 29 July 2005; received in revised form 21 November 2005; accepted 22 November 2005

Available online 9 January 2006

\begin{abstract}
Cowpea crops are severely attacked by Callosobruchus maculatus, a Coleopteran that at the larval stage penetrates into stored seeds and feeds on cotyledons. Cowpea weevil control could be based in utilization of bacteria and fungi to reduce pest development. Entomopathogenic fungi, such as Metarhizium anisopliae, are able to control insect-pests and are widely applied in biological control. This report evaluated ten $M$. anisopliae isolates according to their virulence, correlating chitinolytic, proteolytic and $\alpha$-amylolytic activities, as well proteomic analysis by two dimensional gels of fungal secretions in response to an induced medium containing C. maculatus shells, indicating novel biotechnological tools capable of improving cowpea crop resistance.
\end{abstract}

(C) 2005 Elsevier Inc. All rights reserved.

Keywords: Chitinase; Secretome; Metarhizium anisopliae; Two-dimensional gels; Proteinase

\section{Introduction}

Cowpea (Vigna unguiculata) is a subsistence crop for small holder farmers in Africa and Latin America. These crops are severely attacked by Callosobruchus maculatus, a bruchid that at the larval stage penetrates into stored seeds and seedpods and feeds on cotyledons. This pest significantly reduces the quan-

Abbreviations: MM, minimal medium; MMC, minimal medium $+0.5 \% C$. maculatus exoskeleton; PDA, potato dextrose agar; 3.5 DNS, 3.5 dinitrosalicylic acid; IPG, immobilized pH gradient; DTT, dithiothreitol; SDS-PAGE, sodium dodecylsulfate-polyacrylamide gel electrophoresis.

This paper is part of a special issue of CBP dedicated to "The Face of Latin American Comparative Biochemistry and Physiology" organized by Marcelo Hermes-Lima (Brazil) and co-edited by Carlos Navas (Brazil), Tania ZentenoSavín (Mexico) and the editors of CBP. This issue is in honour of Cicero Lima and the late Peter W. Hochachka, teacher, friend and devoted supporter of Latin American science.

* Corresponding author. Universidade Católica de Brasília, Pós-Graduação em Ciências Gênomicas e Biotecnologia, SGAN 916N - Av W5 - módulo C, Brasília, DF, Brazil. Tel.: +55 61 34487220; fax: +55 613474797.

E-mail address: ocfranco@pos.ucb.br (O.L. Franco). tity and quality of seeds. The development of a single larva in cowpea grains can lead to weight losses of $8-22 \%$, causing up to a $37 \%$ loss in the cowpea crop (Credland et al., 1986).

Cowpea weevil control currently relies on the use of inefficient chemical insecticides, given the to endophytical life cycle and also on biological control (Jackai and Adalla, 1997), which focuses on the use of bacteria, protozoa, nematodes, viruses and fungi (Chapman, 1974; Kaya and Gaugler, 1993; Legner, 1995; Becker and Ascher, 1998; Scholte et al., 2004). In the last few years, several entomopathogenic fungi with the ability to control Coleopteran pests have been investigated (Adane et al., 1996; Moino et al., 1998; Rice and Cogburn, 1999; Bourassa et al., 2001; Kassa et al., 2002). Among them, Beauveria bassiana and Metarhizium anisopliae have been evaluated in order to measure their virulence towards stored bruchid pests (Cherrya et al., 2005). Isolates often perform well in short-term laboratory bioassays, causing enhanced mortality rates within 1-2 weeks, although they may have significant variability in their virulence and host specificity, according to origin and culture history of individual isolates (Cherrya et al., 2005). 
Furthermore, the ascomycete $M$. anisopliae has also been shown capable of penetrating through the insect cuticle, secreting hydrolytical enzymes such as chitinases, proteinases and lipases, commonly referred to as cuticle-degrading enzymes (Moraes et al., 2003; Leger et al., 1986) being effective toward several arthropods (Frazzon et al., 2000; Shah and Pell, 2003; Cherrya et al., 2005). Furthermore, the study of the extracellular proteome from Trichoderma harzianum and their contribution to biocontrol has been receiving increased attention, since this technique was utilized to identify new hydrolytic enzymes involved in colonization process (Suarez et al., 2005).

In this report, insecticidal bioassays of ten different isolate of M. anisopliae were evaluated. Proteinaceous secretions were analyzed in the most virulent isolate by two-dimensional electrophoresis and by chitinolytic, proteolytic and $\alpha$-amylolytic activity, to assess novel biotechnological tools for cowpea weevil control.

\section{Material and methods}

\subsection{Insects and isolates of M. anisopliae}

C. maculatus colonies were maintained in flasks containing cowpea seeds (V. unguiculata) and incubated at $28^{\circ} \mathrm{C}$ with $60-$ $70 \%$ UR. In vitro assays were carried out using adults removed from colonies $24 \mathrm{~h}$ after oviposition. These insects were dehydrated at $49{ }^{\circ} \mathrm{C}$ for $48 \mathrm{~h}$ and macerated for posterior use in bioassays.

Initial screenings were performed using ten isolates of $M$. anisopliae var. anisopliae obtained from the Entomopathogenic Fungal Collection of Embrapa Recursos Geneticos e Biotecnologia (Brasília, Brazil) preserved in liquid nitrogen. Most isolates used in this work were obtained from colonized Coleopteran insect-pests (Table 1).

\subsection{Isolate screening and pathogenicity studies}

Fungi utilized in bioassays were grown on PDA (potato dextrose agar) medium for 15 days at $28{ }^{\circ} \mathrm{C}$. Conidia were suspended in $0.1 \%$ Tween 80 to obtain a dilution of 1 to $4 \times 10^{8}$ conidial $\mathrm{mL}^{-1}$. Conidial solutions $(2.0 \mathrm{~mL})$ were sprayed upon

Table 1

M. anisopliae isolates screened against C. maculatus

\begin{tabular}{llll}
\hline $\begin{array}{l}\text { M. anisopliae } \\
\text { isolate number }\end{array}$ & Host & Origin & $\begin{array}{l}\text { Concentration } \\
\left(\text { conidia } \mathrm{mL}^{-1} \text { ) }\right.\end{array}$ \\
\hline CG34 & Conotrachelus sp. & AM-Brazil & $2.9 \times 10^{8}$ \\
CG38 & Coleoptera: Scarabaeidae & RO-Brazil & $3.3 \times 10^{8}$ \\
CG97 & Coleoptera: Scarabaeidae & DF-Brazil & $2.7 \times 10^{8}$ \\
CG100 & Coleoptera: Scarabaeidae & DF-Brazil & $2.8 \times 10^{8}$ \\
CG210 & Cerotoma arcuata & GO-Brazil & $4.6 \times 10^{8}$ \\
CG236 & Coleomegilla maculate & GO-Brazil & $2.9 \times 10^{8}$ \\
CG256 & Chalcodermus aeneus & GO-Brazil & $1.5 \times 10^{8}$ \\
CG292 & Aphodius tasmaniae & Australia & $1.6 \times 10^{8}$ \\
CG293 & Ancognatha scarabaeoides & Colombia & $1.6 \times 10^{8}$ \\
CG294 & Popillia japonica & Japan & $4.4 \times 10^{8}$ \\
\hline
\end{tabular}

$\mathrm{AM}=$ Amazônia, $\mathrm{RO}=$ Rondônia, $\mathrm{DF}=$ Distrito Federal, $\mathrm{GO}=$ Goiânia.

a Isolate numbers correspond to reference number of Embrapa Recursos Genéticos and Biotechnology Fungal Collection, Brasília, DF, Brazil. insects using a Potter Spray Tower (Burkard Manufacturing, Hertfordshire, England). A control treatment was conducted by spraying with $2.0 \mathrm{~mL} 0.1 \%$ Tween 80 solution. Prior to application, adult insects were immobilized using a $\mathrm{CO}_{2}$ flush. Three replicates (ten insects each) were performed for each isolate. After applications, insects were conditioned in an incubator chamber at $28{ }^{\circ} \mathrm{C}$ and observed daily for mortality assessment. Dead insects were maintained in humidified chambers to confirm if mortality was caused by fungal infection. For bioassays, conidial suspensions at 5 different concentrations were used (CG5: $1.41 \times 10^{5}, 10^{6}, 10^{7}, 10^{8}$ and $10^{9}$ conidia $\mathrm{mL}^{-1}$; CG7: $1.61 \times 10^{5}, 10^{6}, 10^{7}, 10^{8}$ and $10^{9}$ conidia $\mathrm{mL}^{-1}$; CG34: $1.24 \times 10^{5}, 10^{6}, 10^{7}, 10^{8}$ and $10^{9}$ conidia $\mathrm{mL}^{-1}$; and CG100: $1.00 \times 10^{5}, 10^{6}, 10^{7}, 10^{8}$ and $10^{9}$ conidia $\mathrm{mL}^{-1}$ ), using $0.1 \%$ Tween 80 solution as negative control. Each isolate dosage was measured in triplicate. Conidial number deposited per unit of area was calculated and used for equipment calibration according to Vicentini et al. (2001). Application procedures and mortality evaluation were done in the same way as described in screening bioassays. CL50, regression parameters and significance of each isolate were calculated using the Probit method using Micro Probit 3.0 (Thomas and Sparks, 2001). Superposition of confidence intervals of $95 \%$ was used to test statistical differences in CL50s of isolates.

\subsection{Enzyme and secretomic production}

All strains (CG34, CG38, CG97, CG100, CG210, CG236, CG256, CG292, CG293, CG294) isolated from the C. maculatus exoskeleton, were grown in a complete medium $(0.0001 \%$ $\mathrm{FeSO}_{4}, 0.05 \% \mathrm{KCl}, 0.15 \% \mathrm{KH}_{2} \mathrm{PO}_{4}, 0.05 \% \mathrm{MgSO}_{4} \cdot 7 \mathrm{H}_{2} \mathrm{O}$, $0.6 \% \mathrm{NaNO}_{3}, 0.0001 \% \mathrm{ZnSO}_{4}, 0.15 \%$ casein hydrolyzed, $0.05 \%$ yeast extract, $1 \%$ glucose, $0.2 \%$ peptone and $2 \%$ agar) and incubated for 10 days at $28{ }^{\circ} \mathrm{C}$. Spores $\left(10^{7}\right)$ were inoculated in TM medium containing $0.1 \%$ bactopeptone, $0.03 \%$ urea, $0.2 \%$ of $\mathrm{KH}_{2} \mathrm{PO}_{4}, 1.4 \%\left(\mathrm{NH}_{4}\right)_{2} \mathrm{SO}_{4}, 0.03 \% \mathrm{MgSO}_{4} \cdot 7 \mathrm{H}_{2} \mathrm{O}$, $0.3 \% \mathrm{C}_{6} \mathrm{H}_{12} \mathrm{O}_{6}$ and $\mathrm{FeCl}_{3}$ as trace element. After 3 days of incubation, mycelia were transferred to minimal medium (MM) $0.2 \% \mathrm{KH}_{2} \mathrm{PO}_{4}, 0.03 \% \mathrm{MgSO}_{4}, 1.4 \%\left(\mathrm{NH}_{4}\right)_{2} \mathrm{SO}_{4}$ and $\mathrm{FeCl}_{3}$ as trace element, and to MM containing $0.5 \%$ C. maculatus-dehydrated cuticle (MMC). Both were re-incubated for 3 days at $29{ }^{\circ} \mathrm{C}$ at $130 \mathrm{rpm}$ rotation. Both broth were doublefiltered and stored at $-20{ }^{\circ} \mathrm{C}$. In order to standardize all samples, the Bradford method (1976) was used for protein quantification with bovine serum albumin (BSA) as standard. Distilled water served as a negative control.

\subsection{Hydrolytic enzyme assays}

Proteolytic activity in fungal secretions was evaluated according Noronha et al. (2002). $100 \mu \mathrm{g}$ of secreted proteins were added to tubes containing $500 \mu \mathrm{L}$ of $5 \%$ casein $\mathrm{pH} 8.0$ as substrate. Reaction was buffered with $100 \mu \mathrm{L}$ of $0.05 \mathrm{M}$ sodium acetate $\mathrm{pH} 6.8$. After incubation for $30 \mathrm{~min}$ at $40{ }^{\circ} \mathrm{C}$, $1500 \mu 1$ of $5 \%$ tricloroacetic acid was added. Samples were centrifuged at $10000 \times g$ for $15 \mathrm{~min}$ at $4{ }^{\circ} \mathrm{C}$ and the supernatant optical density was measured at $280 \mathrm{~nm}$. Chitinolytic 
Table 2

C. maculatus mortality (media values) caused by different $M$. anisopliae isolates

\begin{tabular}{lc}
\hline M. anisopliae var. anisopliae & \\
\hline Isolate & Mortality (\%) \\
\hline CG34 & 26.7 \\
CG292 & 14.2 \\
CG100 & 10.0 \\
CG38 & 0.0 \\
CG97 & 0.0 \\
CG210 & 0.0 \\
CG236 & 0.0 \\
CG256 & 0.0 \\
CG293 & 0.0 \\
CG294 & 0.0 \\
Control & 0.0 \\
\hline
\end{tabular}

Each assay was carried out in triplicate, not differing more than $12 \%$.

activity was detected as previously described by Ulhoa and Peberdy (1992). Assays were conducted using $186 \mu \mathrm{g} \mathrm{mL}$ concentration. For negative controls, $500 \mu \mathrm{l}$ of MMC and MM boiled samples were added in flasks containing $500 \mu \mathrm{L}$ of $1 \%$ colloidal chitin at $\mathrm{pH} 5.0$ as substrate. The same procedure was done with MMC and MM un-boiled samples. Triplicate assays were incubated for $6 \mathrm{~h}$ at $37{ }^{\circ} \mathrm{C}$. Samples $(250 \mu \mathrm{L})$ were transferred to tubes containing $1000 \mu \mathrm{L}$ of $1 \%$ 3,5-dinitrosalicylic acid (3,5-DNS) and boiled for 5 min. Both reactions were analyzed with a spectrophotometer at $530 \mathrm{~nm}$. An acetylglucosamine glucose curve was carried out as standard as described by Miller (1959). $\alpha$-Amylase activity was determined according to Bernfeld (1955) in sodium acetate buffer $0.05 \mathrm{M}$, pH 6.8. $250 \mu \mathrm{L}$ of $1 \%$ starch was added as substrate and each fraction was incubated at $37^{\circ} \mathrm{C}$ for $20 \mathrm{~min}$. Enzyme activities were determined in triplicate by adding 1.0 $\mathrm{mL}$ 3,5-DNS (1\% dinitrosalicylic acid, $0.2 \mathrm{~N} \mathrm{NaOH}, 30 \% \mathrm{Na} /$ $\mathrm{K}$-tartrate). Optical density was measured at $530 \mathrm{~nm}$. One enzyme unit $(1 \mathrm{U})$ was defined as the amount of enzyme that increased the absorbance by 0.1 OD during timed assays described before. Each assay was carried out in triplicate.

\subsection{Gel electrophoresis}

Isoelectric focusing and molecular mass separation were conducted according to Gorg et al. (1988) using 18-cm immobilized $\mathrm{pH}$ gradient (IPG) strips with a $\mathrm{pH}$ range of 3-10 and a Multiphor II electrophoresis system from General Electric.

Table 3

CL50 (95\% fiducial limits) and regression parameters $a$ ( $y$-intercept) and $b$ (slope) (estimated by probit method) for four fungal isolates tested in adults of C. maculatus

\begin{tabular}{lllll}
\hline M. anisopliae & CL $50\left(\right.$ conidia $\left.\mathrm{cm}^{-2}\right)$ & $a$ & $\mathrm{~b} \pm$ S.E. & $\chi^{2}$ \\
\hline CG34 & $1.4 \times 10^{4}\left(6.5 \times 10^{3}-2.9 \times 10^{4}\right)$ & 1.8 & $0.8 \pm 0.1 \mathrm{~b}$ & $4.2 \mathrm{~ns}$ \\
CG100 & $1.8 \times 10^{4}\left(5.9 \times 10^{3}-5.1 \times 10^{4}\right)$ & 2.9 & $0.5 \pm 0.1 \mathrm{c}$ & $7.1 \mathrm{~ns}$ \\
\hline
\end{tabular}

$\chi^{2}$ indicates data adjustment to probit model.

Values of $b$ followed by different minus letters indicate significant statistical differences (ANOVA: $F_{(3,16)}=34.37, p<0.001$; and Student-Newman-Keuls test: $p<0.05)$.
Strips containing $200 \mu \mathrm{g}$ of MMC and MM were rehydrated with 2\% CHAPS, $8 \mathrm{M}$ urea, $7 \mathrm{mg}$ dithiothreitol (DTT) and 2\% IPG buffer for $16 \mathrm{~h}$ following isoelectric focusing, which was carried out for $380 \mathrm{~min}$ at $3 \mathrm{kV}, 2 \mathrm{~mA}$ and $5 \mathrm{~W}$. After the first dimension, strips were equilibrated in a solution containing $6 \mathrm{M}$ urea, $1 \%$ DTT and $2 \%$ SDS for 15 min and then applied to gels. SDS-PAGE second dimension $\left(18 \times 24 \mathrm{~cm}^{2}\right)$, as well as mini gels were performed at $12.5 \%$ as described by Laemmli (1970).


Fig. 1. Comparative chitinolytic (A), proteolytic (B) and $\alpha$-amylolytic (C) activities of $M$. anisopliae secretion in absence (MM) and presence (MMC) of C. maculatus exoskeleton. Vertical bars correspond to standard deviation. 


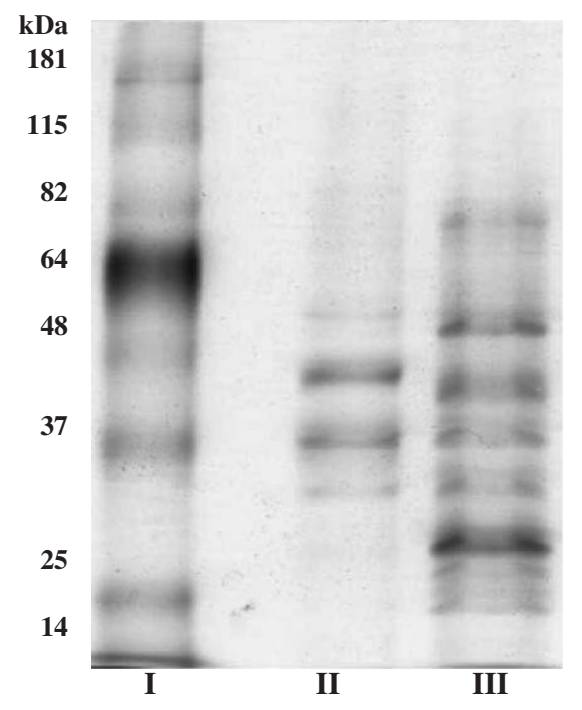

Fig. 2. SDS-PAGE analysis of M. anisopliae secreted proteins in the absence (lane II) and presence (lane III) of $0.5 \%$ C. maculatus shells. Lane I corresponds to molecular weight marker.

In both, bromophenol blue was used as tracking dye. Electrophoresis was conducted of $250 \mathrm{~V}, 50 \mathrm{~mA}$ and $10 \mathrm{~W}$ for $10 \mathrm{~h}$. Spots were silver-stained.

\section{Results and discussion}

An initial screening revealed the pathogenicity of M. anisopliae towards the cowpea weevil C. maculatus. Bioassays indicated that three isolates (CG34, CG292 and CG100) demonstrated lethal activity against bruchids, causing considerable mortalities (Table 2). For isolates CG34 and CG100, CL50 tests were performed, showing no statistical differences between isolates (confidence interval superposition criteria $p<0.05$ ).
CL50 isolated tested were done in the range of 1 to $5 \times 10^{4}$ conidia $\mathrm{cm}^{-2}$ (Table 3). A statistical difference was found between values of slope regression line (Table 3 ) indicating that, despite similar CL50 values, the isolate CG 34 showed increased lethality.

As previously described, supernatant obtained from minimal medium in the presence and absence of $C$. maculatus exoskeleton were double filtered after 24, 48 and $72 \mathrm{~h}$ of incubation. After 3 days, $267 \mu \mathrm{g} \mathrm{mL}^{-1}$ protein concentration was observed in MMC, while only $49 \mu \mathrm{g} \mathrm{mL}^{-1}$ was found in MM. These data clearly indicate enhanced protein concentration in response to C. maculatus exoskeleton presence. Additionally, to verify hydrolytic enzymes secreted by $M$. anisopliae, chitinolytic, proteolytic and $\alpha$-amylolytic assays were performed using isolate CG34. This isolate was observed to have high chitinolytical and proteolytical activities and a low $\alpha$-amylolytical activity in MMC. Nevertheless very low enzyme activity rates were detected in MM (Fig. 1A, B, C). These results were expected since the unique carbon and nitrogen sources supplied to the fungus were derived from chitin-rich and protein-rich exoskeletons. An enhanced production of proteinases and chitinase clearly demonstrate an expression induced by the presence of specific substrates. In contrast, low $\alpha$-amylolytical activity was detected in MMC, since insect shells do not contain starch.

To analyze fungal secretion, $100 \mu \mathrm{g}$ of each sample were applied in a $12.5 \%$ SDS-PAGE gel (Fig. 2) showing proteins produced by $M$. anisopliae in induced and non-induced broth. Numerous protein bands with diverse molecular masses could be visualized in MMC, with approximately $27 \mathrm{kDa}, 30 \mathrm{kDa}, 37$ $\mathrm{kDa}, 45 \mathrm{kDa}, 50 \mathrm{kDa}$ and $80 \mathrm{kDa}$ (Fig. 2, Lane III). MM revealed less protein diversity, with a protein range of 35 to $57 \mathrm{kDa}$, approximately (Fig. 2, Lane II). For a more detailed protein characterization, 2D gels were carried out showing a wide protein range in both MMC/MM samples (Fig. 3). Only 4

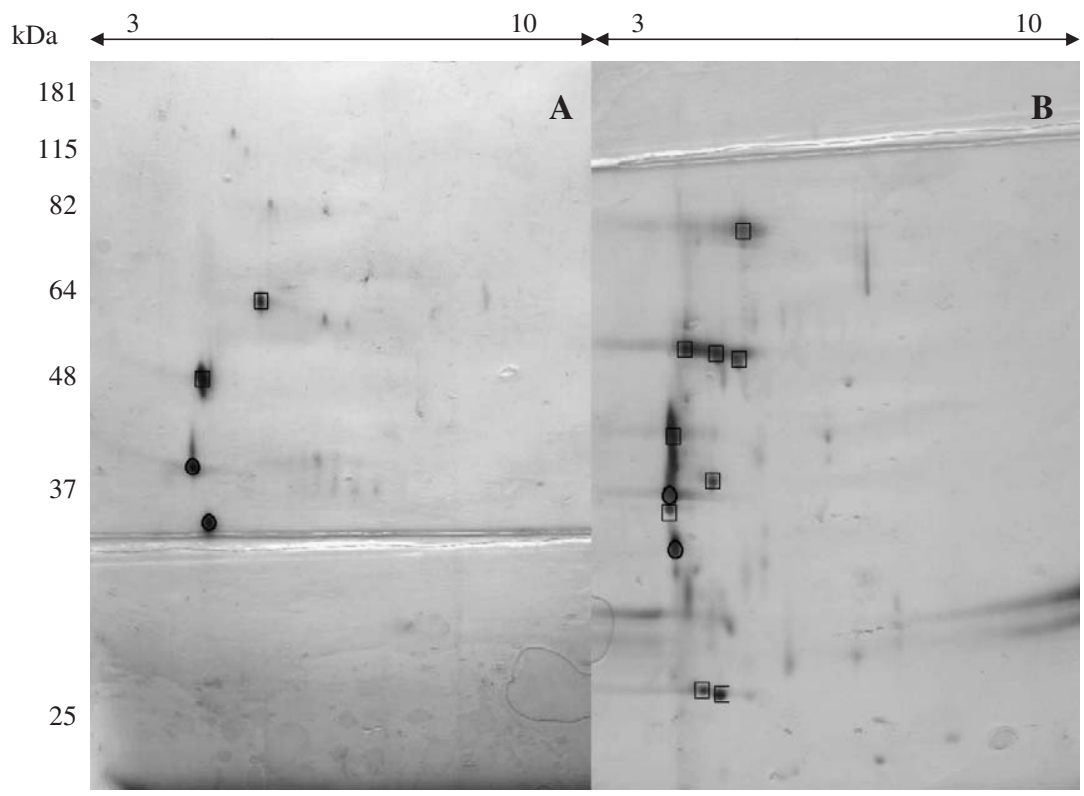

Fig. 3. MM (A) and MMC (B) samples analyzed by two-dimensional gels. Circled spots identify identical matches in MMC and MM gels. Black arrows correspond to $\mathrm{p} I$ wide ranges. Square identifies main differential putative proteins expressed in response to insect shells. Both gels were silver-stained and each one was carried out in triplicate. 
spots were observed in MM (Fig. 3A), while 11 significant spots were identified in MMC (Fig. 2A). Only two spots were found at an identical position in both gels with molecular masses of $30 \mathrm{kDa}$ and $37 \mathrm{kDa}$. In contrast, two other spots with approximately $47 \mathrm{kDa}$ and $57 \mathrm{kDa}$ are present only in $\mathrm{MM}$ and all other spots (6) were observed with induced fungal secretion, with molecular masses of $27 \mathrm{kDa}, 35 \mathrm{kDa}, 39 \mathrm{kDa}$, $45 \mathrm{kDa}, 50 \mathrm{kDa}$ and $80 \mathrm{kDa}$ respectively (Fig. 3).

The proteins secreted by CG34 showed similar molecular mass patterns, as described in other reports. Leger et al. (1996, 1998, 1999) described two trypsin-like proteinases synthesized by $M$. anisopliae in response to cockroach (Periplaneta americana) shells, with isoelectric points of $\mathrm{pH} 4.4$ and $\mathrm{pH} 4.9$, and molecular masses of $30 \mathrm{kDa}$ and $27 \mathrm{kDa}$, respectively, as observed in Fig. 3B marked by squares. Furthermore, Leger et al. (1996) also determined a major chitinase form of $45 \mathrm{kDa}$, which also was observed by proteomic experiments (Fig. 3B). In conclusion, analyses suggested that CG34 MMC samples produced two trypsin-like serine proteinases with $27 \mathrm{kDa}$ and 30 $\mathrm{kDa}$ and also a chitin deacetylase isoform of $45 \mathrm{kDa}$ (Nahar et al., 2004). These results were supported by our enzymatic assays (Fig. 1). To elucidate functions in other spots and their involvement in fungal colonization, further studies will be carried out using peptide mass fingerprinting and Edman degradation sequencing. According Shimizu and Wariishi (2005), quantitative comparisons of proteome maps prepared from mycelial and protoplast cells indicated protein spots with a wider range of molecular weights and $\mathrm{p} I$ values. In this field, a proteomic approach has been recently used to display the mycelial and secreted proteins related to the biocontrol response in Trichoderma atroviride (Grinyer et al., 2004). The report identified several hydrolytic degrading enzymes with different degree of similarity to proteins described previously. Similar results recently described were observed for T. harzianum secretome (Suarez et al., 2005), where proteinases were expressed in induced conditions, as observed in results here presented. These data may be used in the development and production of novel highly specific bioinsecticides, non-target organism-safe, with biodegradable properties, and also in engineering of transgenic plants for enhancement of bruchid resistance.

\section{Acknowledgments}

CAPES, CNPq and UCB supported this work. Authors thank to Diogo P. da Silva for providing insect-shells and Robert Gerard Miller for English review.

\section{References}

Adane, K., Moore, D., Archer, S.A., 1996. Preliminary studies on the use of Beauveria bassiana to control Sitophilus zeamais (Coleoptera: Curculionidae) in the laboratory. J. Stored Prod. Res. 32, 105-113.

Becker, N., Ascher, K.R.S., 1998. The use of Bacillus thuringiensis subsp. israelensis (Bti) against mosquitoes, with special emphasis on the ecological impact. Isr. J. Entomol. 32, 63-69.

Bernfeld, P., 1955. Amylases alpha and beta. Methods Enzymol. 1, 149-150.

Bourassa, C., Vincent, C., Lomer, C.J., Borgemeister, C., Mauffette, Y., 2001. Effects of entomopathogenic Hyphomycetes against the larger grain borer,
Prostephanus truncatus (Horn) (Coleoptera: Bostrichidae), and its predator, Teretriosoma nigrescens Lewis (Coleoptera: Histeridae). J. Invertebr. Pathol. 77, 75-77.

Bradford, M., 1976. A rapid and sensitive method for the quantization of microgram quantities of protein utilizing the principle of protein-dye binding. Anal. Biochem. 72, 248-254.

Chapman, H.C., 1974. Biological control of mosquito larvae. Annu. Rev. Entomol. 19, 33-59.

Cherrya, A.J., Abalob, P., Hella, K., 2005. A laboratory assessment of the potential of different strains of the entomopathogenic fungi Beauveria bassiana (Balsamo), Vuillemin and Metarhizium anisopliae (Metschnikoff) to control Callosobruchus maculatus (F.) (Coleoptera: Bruchidae) in stored cowpea. J. Stored Prod. Res. 41, 295-309.

Credland, P.F., Dick, K.M., Wright, A.W., 1986. Relationship between larval density, adult size and egg production in cowpea seed beetle, Callosobruchus maculatus. Ecol. Entomol. 11, 41-50.

Frazzon, A.P.G.., Vaz Jr., I.S., Masuda, A., Schrank, A., Vainstein, M.H., 2000. In vitro assessment of Metarhizium anisopliae isolates to control the cattle tick Boophilus microplus. Vet. Parasitol. 94, 117-125.

Gorg, A., Postel, W., Gubther, S., 1988. The current state of two-dimensional electrophoresis with immobilized $\mathrm{pH}$ gradients. Electrophoresis 9, 531-546.

Grinyer, J., McKay, M., Nevalainen, H., Herbert, B.R., 2004. Fungal proteomics: initial mapping of biological control strain Trichoderma harzianum. Curr. Genet. 45, 163-169.

Jackai, L.E.N., Adalla, C.B., 1997. Pest management practices in cowpea: a review. In: Singh, B.B., Mohan Raj, D.R., Dashiell, K.E., Jackai, L.E.N. (Eds.), Advances in Cowpea Research. International Institute of Tropical Agriculture(IITA) and Japan International Research Center for Agricultural Sciences (JIRCAS). IITA, Ibadan, Nigeria, 240-258.

Kassa, A., Zimmermann, G., Stephan, D., Vidal, S., 2002. Susceptibility of Sitophilus zeamais (Motsch.) (Coleoptera: Curculionidae) and Prostephanus truncatus (Horn) (Coleoptera: Bostrichidae) to entomopathogenic fungi from Ethiopia. Biochem. Sci. Technol. 12, 727-736.

Kaya, H.K., Gaugler, R., 1993. Entomopathogenic nematodes. Annu. Rev. Entomol. 38, 181-206.

Laemmli, U.K., 1970. Cleavage of structural proteins during the assembly of the head of bacteriophage $T_{4}$. Nature 227, 680-685.

Leger, R.J.S., Cooper, R.M., Charnley, A.K., 1986. Cuticle degrading enzymes of entomopathogenic fungi: regulation of production of chitinolytic enzymes. J. Gen. Microbiol. 132, 1509-1517.

Leger, R.J.S., Lokesh, J., Bidochka, M.J., Rizzo, N.W., Roberts, D.W., 1996. Biochemical characterization and ultrastructural localization of two extracellular trypsins produced by Metarhizium anisopliae in infected insect cuticles. Appl. Environ. Microbiol. 62, 1257-1264.

Leger, R.J.S., Lokesh, J., Donald, R., 1998. Ambient pH is a major determinant in the expression of cuticle-degrading enzymes and hydrophobin by Metarhizium anisopliae. Appl. Environ. Microbiol. 64, 709-713.

Leger, R.J.S., Nelson, J.O., Screen, S.E., 1999. The entomopathogenic fungus Metarhizium anisopliae alters ambient $\mathrm{pH}$, allowing extracellular proteinase production and activity. Microbiology 145, 2691-2699.

Legner, E.F., 1995. Biological control of Diptera of medical and veterinary importance. J. Vector. Ecol. 20, 59-120.

Miller, G.L., 1959. Use of dinitrosalicylic acid reagent for determination of reducing sugar. Anal. Chem. 31, 426-428.

Moino, A., Alves, S.B., Pereira, R.M., 1998. Efficacy of Beauveria bassiana (Balsamo) vuillemin isolates for control of stored-grain pests. J. Appl. Entomol. 122, 301-305.

Moraes, C.K., Schrank, A., Vainstein, M.H., 2003. Regulation of extracellular chitinase and proteases in the entomopathogen and acaricide Metarhizium anisopliae. Curr. Microbiol. 46, 205-210.

Nahar, P., Ghormade, V., Deshpande, M.V., 2004. The extracellular constitutive production of chitin deacetylase in Metarhizium anisopliae: possible edge to entomopathogenic fungi in the biological control of insect pests. J. Invert. Pathol. 85, 80-88.

Noronha, E.F., Lima, B.D., Sá, C.M., Felix, C.R., 2002. Heterologous expression of Aspergillus fumigatus keratinase in Pichia pastoris. Seminário Brasileiro de Tecnologia Enzimática, Brasília. 
Rice, W.C., Cogburn, R.R., 1999. Activity of entomopathogenic fungus Beauveria bassiana (Deuteromycota: Hyphomycetes) against three coleopteran pests of stored grain. J. Econ. Entomol. 92, 691-694.

Scholte, E.J., Knols, B.G.J., Samson, R.A., Takken, W., 2004. Entomopathogenic fungi for mosquito control. J. Insect Sci. 24, 4-19.

Shah, P.A., Pell, J.K., 2003. Entomopathogenic fungi as biological control agents mini-review. Appl. Microbiol. Biotechnol. 61, 413-423.

Shimizu, M., Wariishi, H., 2005. Development of a sample preparation method for fungal proteomics. FEMS Microbiol. Lett. 247, 17-22.

Suarez, M.B., Sanz, L., Chamorro, M.I., Rey, M., González, F.J., Llobell, A., Monte, E., 2005. Proteomic analysis of secreted proteins from Trichoderma harzianum: identification of a fungal cell wall-induced aspartic protease. Fungal Genet. Biol. 42, 924-934.

Thomas, C. and Sparks, A., 2001. Micro Probit 3.0. Probit Analysis for the IBM $\mathrm{PC}$ and Compatibles.

Ulhoa, C.J., Peberdy, J.F., 1992. Purification and some properties of the extracellular chitinase produced by Trichoderma harzianum. Enzyme Microb. Technol. 14, 236-240.

Vicentini, S., Faria, M., Oliveira, M.R.V., 2001. Screening of Beauveria bassiana (Deuteromycotina: Hyphomycetes) isolates against nymphs of Bemisia tabaci (Genn.) biotype B (Hemiptera: Aleyrodidae) with description of a new bioassay. Method. Neotro. Entomol. 30, 97-103. 